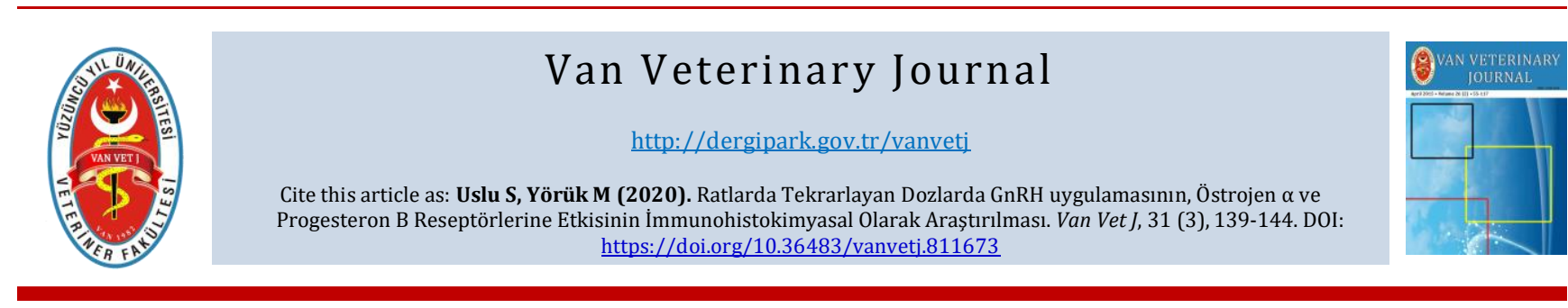

\title{
Immunohistochemically Investigation of the Effect of Repeated Doses of GnRH on Oestrogen $\alpha$ and Progesterone B Receptors in Rats
}

\author{
Sema USLU1] Mecit YÖRÜK²] \\ ${ }^{1}$ Burdur Mehmet Akif Ersoy University, Faculty of Veterinary Medicine, Department of Histology and Embryology, Burdur, Turkey \\ ${ }^{2}$ Van Yuzuncu Yil University, Faculty of Veterinary Medicine, Department of Histology and Embryology, Van, Turkey
}

Received: 16.10 .2020

Accepted: 04.11.2020

ABSTRACT The present study aimed to determine the effect of repeated doses of GnRH injection on the distribution of estrogen and progesterone receptors In the study $(n=24)$ rats were used. Trial groups; control group with placebo injection $(n=6)$, Group $1(n=6)$ with single GnRH injection, Group $2(n=6)$ with 5 consecutive days of GnRH, Group 3 with repeated doses of $\mathrm{GnRH}$ for 10 days $(n=6)$ randomly divided into 4 groups. At the end of the application, the ovary and uterus were removed from the sacrified rats and the histological tissue was blocked after the follow-up procedure. The cut tissues were examined immunohistochemically in terms of estrogen, progesterone receptor distribution, and staining intensity. When ovaries are evaluated in control and 1 group; Estrogen $\alpha$ receptors were seen as $(+)$ in granulosa cells in follicles, primary, secondary and graaf in granulosa cells in follicle wall. (+) Reactions were detected in germinative epithelium, vascular wall endothelial cells, smooth muscle cells and interstitial cells. In the tissue samples taken from the corn and corpus uteri sections, $(+)$ reactions were observed in the endometrial epithelium. In groups 2 and 3 , reactions with different intensity in terms of staining intensity were detected in similar settlements in the ovary. Progesterone B receptors; It was observed that corpus luteum luteal cells, germinative epithelium, theca interna / externa cells showed positive reactions in groups 1, 2, 3 and 4, and the intensity of staining varied between groups. While $(+)$ reactions were detected in the endometrium epithelium, stratum basalis region, myometrium, and perimetrium in the corn and corpus uterus, no $(+)$ reaction was detected in the myometrium region in the control group samples.

Keywords: Immunohistochemical,Oestrogen receptor $\alpha$, Ovary, Progesterone receptor B,Uterine

öz

\section{Ratlarda Tekrarlayan Dozlarda GnRH uygulamasının, Östrojen $\alpha$ ve Progesteron B Reseptörlerine Etkisinin İmmunohistokimyasal Olarak Araştırılması}

Sunulan bu çalışma da, tekrarlayan dozlarda GnRH enjeksiyonunun östrojen ve progesteron reseptörlerinin dağılımına etkisinin belirlenmesi amaçlandı. Çalışmada $(n=24)$ adet rat kullanıldı. Gruplar; hiçbir uygulama yapılmayıp placebo enjeksiyonu yapılan kontrol grubu $(n=6)$, tek GnRH enjeksiyonu yapılan Grup $1(n=6), 5$ gün üst üste GnRH enjeksiyonu yapılan Grup $2(\mathrm{n}=6)$, 10 gün süreyle tekrarlayan dozlarda GnRH uygulanan Grup $3(n=6)$ olarak rastgele 4 gruba ayrild. Uygulama sonunda sakrifiye edilen ratlardan ovaryum ve uteruslar alınarak histolojik doku takip prosedürü ardından bloklandı. Kesilen dokular immunohistokimyasal olarak östrojen, progesteron reseptörlerinin dağılımı ve boyanma şiddeti yönünden incelendi. Kontrol ve 1 grupta ovaryumlar değerlendirildiğinde; Östrojen $\alpha$ reseptörlerinin, foliküllerdeki granüloza hücrelerinde, primer, sekunder ve graaf folikül duvarında granüloza hücrelerinde $(+)$ olarak görüldü. Germinatif epitelde, damar duvarı endotel hücreleri, düz kas hücrelerinde ve interstisyel hücrelerde $(+)$ reaksiyonlar tespit edildi. Kornu ve korpus uteri bölümlerinden alınan doku örneklerinde ise endometriyum epitelinde (+) reaksiyonlar görüldü. Grup 2 ve 3'te, ovaryum da benzer yerleşim bölgelerinde fakat boyanma șiddeti yönünden farklı şiddette reaksiyonlar tespit edildi. Progesteron B reseptörlerinin; Grup 1,2,3 ve 4'te korpus luteum luteal hücreleri, germinatif epitel, teka interna / eksterna hücreleri pozitif reaksiyon gösterdiği, gruplar arasında boyanma şiddetinin değiștiği görüldü. Kornu ve korpus uteride endometriyum epiteli, stratum bazalis bölgesi, miyometriyum ve perimetriyumda $(+)$ reaksiyonlar tespit edilirken kontrol grubu örneklerinde miyometriyum bölgesinde $(+)$ reaksiyon tespit edilemedi.

Anahtar Kelimeler: Immunohistokimya, Ostrojen reseptor $\alpha$, Ovaryum, Progesteron reseptor B, Uterus 


\section{GíRiş}

Gonadotropin-salgılatıcı hormon (GnRH) gonadotropinler diye bilinen, folikül stimülan hormon (FSH) ve lüteinleştirici hormon (LH)'ın ve sonrasında gonadal hormonların sentezini ve sekresyonunu kontrol eden dekapeptit yapılı bir hormondur (King ve Millar 1995). En iyi bilinen ovaryum salgıları steroid hormonlardır ve bu salgılar ovaryumdaki korpus luteumdan, çeşitli aşamalardaki foliküllerden, interstisyel hücrelerden salgılanırlar (Schams ve Berisha 2002). Ovaryumdan salgılanan steroid hormonların başlıcaları östrojen ve progesterondur. $\mathrm{Bu}$ hormonlar dişilerde üreme organlarının morfolojik ve fonksiyonel değişimlerinin kontrolünde rol oynarlar (Srisuwatanasagul ve ark. 2009).

Östrojen, steroidogeneziste ve folikülogeneziste iyi bilinen bir düzenleyicidir. Östrojen ovaryum granüloza hücre proliferasyonunu uyararak foliküler gelişimi düzenlemektedir. Granüloza hücrelerinden FSH salgısının artması ve granüloza hücreleri arasındaki etkileşim bilinmektedir (Drummond ve Findlay 1999; Merk ve ark. 1972). Ovaryum içi östrojenle ilgili hareketlerde ovaryum dokusu içerisinde dağınık olarak bulunan Östrojen reseptörü alfa $(E R \alpha)$ ve östrojen reseptörü beta (ER $\beta$ ) adlı iki spesifik östrojen reseptörü bulunmaktadır (HulasStasiak ve Gawron 2007). Yapllan immuno-histokimyasal çalışmalar birçok hayvan türünde bu iki östrojen reseptörünün yerleşimini ve dağılımını ortaya koymuştur (Hild -Petito ve ark., 1988; Chiang ve ark. 2000; Rosenfeld ve ark. 1999; Slomczynska ve Wozniak 2001).

Progesteron hormonu memelilerde reprodüktif faaliyetleri düzenleyen, korpus luteum tarafından sentezlenen bir hormondur (Dellman ve Eurell 1988). Progesteron hedef dokularda spesifik hücre içi progesteron reseptörlerine (PR) bağlandıktan sonra etkili olur. Progesteron reseptörlerinin iki izoformu bulunmaktadır, bunlar Progesteron reseptör A (PR-A), Progesteron reseptör B (PR-B) dir (Graham ve Clarke 1997). Progesteron reseptör C (PR-C) adı verilen fakat göğüs kanseri gibi patolojik durumlarda belirlenen progesteron reseptörü de vardır (Wei ve Miner 1994). Progesteron reseptörleri, östrüs siklusunun farklı aşamalarında ovaryumda sığırlar, köpekler gibi farklı hayvanlarda çalışılmıștır (Van den Broeck ve ark. 2002; Vermeirsch ve ark. 2001).

\section{MATERYAL ve METOT}

\section{Hayvanların Gruplandırılması ve Dokuların Alınması}

Çalışmanın planlanması sürecinde, Cumhuriyet Üniversitesi Hayvan Deneyleri Yerel Etik Kurulu'ndan 07.01.2016 tarihinde 65202830-050.04.04.06 sayll izin alınarak yapılmıştır.

Çalışmanın için kullanılan hayvanlar, 250-300 gr ağırlığındaki $(n=24)$ Wistar Albino dişi ratlar, Kontrol grubu $(\mathrm{n}=6)$ 0,3 ml placebo (fizyolojik tuzlu su) njeksiyonu yapılmıștır. Grup1 (n=6) tek doz (0,3 ml) GnRH (Lesirelin asetat, $25 \mu \mathrm{g} / \mathrm{ml})$, Grup 2 ( $\mathrm{n}=6), 5 \mathrm{doz}(0,3 \times 5=1,5 \mathrm{ml}) \mathrm{GnRH}$ (Lesirelin asetat, $25 \mu \mathrm{g} / \mathrm{ml})$, Grup $3(\mathrm{n}=6) 10 \mathrm{doz}(0,3 \mathrm{x}$ $10=3,0 \mathrm{ml}$ ) $\mathrm{GnRH}$ (Lesirelin asetat, $25 \mu \mathrm{g} / \mathrm{ml}$ ) enjeksiyonu yapılan ratlar olarak rastgele gruplandırıldı. Her gruptaki hayvanlar son enjeksiyon yapılan günden 1 gün sonra sakrifiye edilerek ovaryum ve uterusları alındı.

Elde edilen ovaryumlar ve uteruslar, morfolojik görünümleri değerlendirilip \% 10’luk tamponlu nötr formaldehit içerisinde 24 saat süreyle tespit edilip, rutin histolojik metotlarla ișlenerek paraplast ile bloklandı (Bancroft ve Cook 1984). Her bir dokudan elde edilen $4 \mu \mathrm{m}$ kalınlığındaki seri kesitler, PR- B reseptörü ve ER $\alpha$ belirleyebilmek amaciyla immuno-histokimyasal olarak boyandl.

\section{İmmunohistokimyasal Prosedür}

İmmuno-histokimyasal olarak dokular $\mathrm{ABC}$ metoduyla, Abcam tarafindan belirlenen protokole göre boyandı. Doku kesitleri $(4 \mu \mathrm{m})$ polysine ile kaplı lamlara alındı (Thermo scientific, Menzel -Glaser, Germany). Deparafinize edilen kesitlere rehidrasyon sonrası, antijen retrival (citreate buffer\%10 pH: 6) 40dk kaynatarak uygulandı. Oda Isısında soğutulduktan sonra (\%3 methanolde) H2O2de $20 \mathrm{dk}$ nonspesifik boyanmaları önlemek için peroksidaz blokajı yapıldı. PBS yıkamasından sonra 1/5 konsantrasyonda rabbit serum $10 \mathrm{dk}$ inkübe edilerek protein blokaj yapıldı. 1/100 konsantrasyonda östrojen $\alpha$ (Santa Cruz Bioteknology- 53493), 1/50 konsantrasyonda PR B (Santa Cruz Bioteknology-2615) primer antikorları ile oda ısısında 2 saat inkübe edildi. PBS ile yıkama yapıldı. $20 \mathrm{dk}$ biotin uygulandl, $20 \mathrm{dk}$ PBS yıkamasından sonra $20 \mathrm{dk}$ streptavidin peroksidaz uyguland. PBS sonrası $10 \mathrm{dk}$ AEC (zymed, 3- Amino-9-ethylcarbazole) takiben Mayer's hematoksileni ile zemin boyaması yapıldı, su bazlı yapıştırıcı ile kapatıldı.

\section{Semikantitatif Analiz ve Skorlama}

Ovaryum, kornu uteri ve korpus uteri bölümleri ER $\alpha$ ve progesteron $B$ reseptörlerinin İmmünohistokimyasal olarak (+) reaksiyon vermelerine göre farklı iki araştırmacı (Uslu S. ve Yörük M.) tarafından değerlendirildi ve ortalama değerler bulgular bölümüne eklendi. İmmunohistokimyasal olarak AEC kromojen ile kırmızı boyananlar (+) reaksiyon verenler olarak, kırmızı boyanma görülmeyenler ise (-) reaksiyon verenler olarak adlandırıldı. Araştırmadaki sonuçlar boyanma yoğunluğu ve boyanma şiddeti olarak iki şekilde semi-kantitatif biçimde oluşturuldu. Boyanma yoğunluğu skoru, stoplazma, çekirdek ve membranda bulunan pozitif alanları yansitmaktadır. \% 0: boyanma yok, 0. (-) \%00 $\% 20$ : zayıf yoğunluk, 1. (+) \% 20 -50: orta yoğunluk, 2. (++) \% 50- 80 : yoğun 3. (+++) Boyanma şiddeti; boyanma yok : 0, (-) zayıf reaksiyon: $1,(+)$ Orta reaksiyon: $2,(++)$ güçlü reaksiyon: $3(+++)$ şeklinde değerlendirildi (Brown ve Lamartinere 2000).

\section{BULGULAR}

\section{ER $\alpha$ Bulguları}

Kontrol, Grup 1, 2, 3'e ait ovaryum örnekleri değerlendirildiğinde foliküllerdeki granüloza hücrelerinde primer, sekonder ve graf folikül duvarında granüloza hücrelerinde $(+)$ reaksiyon olduğu görüldü. Germinatif epitelde ER $\alpha$ reseptörleri (+) olarak belirlendi. Damar duvarı endotel hücreleri, düzkas hücrelerinde ve İnterstisyel hücrelerde $(+)$ reaksiyonlar tespit edildi (Tablo 1).

Kornu ve korpus uteri bölümlerinden alınan doku örneklerinde endometriyum epiteli, stratum bazalis yakınlarındaki stromal bölge, miyometriyum ve perimetriyum bölgesindeki (+) reaksiyonlar değerlendirildiğinde; Gup 1, 2, 3 te endometriyum epiteli, stratum bazalis, ve myometriyumda (+) reaksiyonlar belirlendi.

\section{PR B Bulguları}

Ovaryum doku örnekleri PR B reseptörlerinin korpus luteum luteal hücreleri, korpus albikans hücreleri, germinatif epitel, teka interna/eksterna hücreleri ve stromal hücrelerde incelenerek kontrol grubu, Grup 1, 2, 3 
te pozitif reaksiyon ve boyanma şiddetinin değiştiği görüldü (Tablo 1).

Kornu ve korpus uteri kontrol grubu, Grup 1, 2, 3'te endometriyum epiteli, stratum bazalis bölgesi, miyometriyum ve perimetriyumda $(+)$ reaksiyonlar tespit edilirken kontrol grubu örneklerinde miyometriyum bölgesinde (+) PR B reaksiyonu tespit edilemedi.

Tablo 1. GnRH enjeksiyonu sonrası ovaryum, korpus ve kornu uterilerinde ER $\alpha$ ve PR B'nin immunohistokimyasal lokalizasyonlarının boyanma şiddeti ve yoğunluk ortalaması skoru.

Table 1. The staining intensity and intensity mean score of the immunohistochemical localizations of ER $\alpha$ and PR B in the ovary, corpus and cornu uteri after GnRH injection.

\begin{tabular}{|c|c|c|c|c|c|c|c|c|}
\hline \multirow[b]{2}{*}{ Ovaryum } & \multicolumn{4}{|c|}{$\mathrm{ER} \alpha$} & \multicolumn{4}{|c|}{ PR-B } \\
\hline & Kontrol & Grup 1 & Grup 2 & Grup 3 & Kontrol & Grup 1 & Grup 2 & Grup 3 \\
\hline Germinatif epitel & + & + & + & +++ & ++ & ++ & ++ & ++ \\
\hline Granüloza hücreleri & ++ & ++ & +++ & ++ & - & - & - & - \\
\hline Teka eks/teka int & $-/+$ & $-/+$ & $-/+$ & $-/+$ & $-/+$ & $-/+$ & $-/+$ & $-/+$ \\
\hline $\begin{array}{l}\text { Korpus } \\
\text { luteum/Korpus } \\
\text { albikans }\end{array}$ & & & & & $-/+$ & $-/+$ & $-/+$ & $-/+$ \\
\hline \multicolumn{9}{|l|}{ Kornu ve Korpus uteri } \\
\hline Yüzey epiteli & $+/+$ & $+/+$ & $+/+$ & $+/+$ & $+/+$ & $+/+$ & $+/+$ & $+/+$ \\
\hline $\begin{array}{l}\text { Str bazalis ve bağ } \\
\text { doku }\end{array}$ & $+/+$ & $+/+$ & $+/+$ & $+/+$ & $-/-$ & $+/+$ & $+/+$ & $+/+$ \\
\hline $\begin{array}{l}\text { Miyometriyum ve } \\
\text { perimetriyum }\end{array}$ & $++/++$ & $++/++$ & $++/++$ & $++/++$ & $-/-$ & $++/++$ & $++/++$ & $++/++$ \\
\hline
\end{tabular}

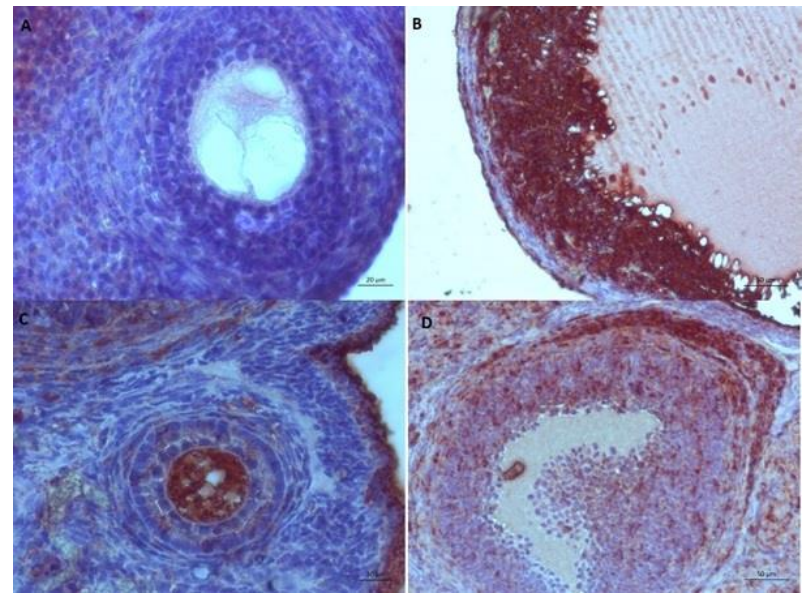

Șekil 1. Ovaryum östrojen $\alpha$ boyamalarının Grup 1, 2, 3 de gösterimi. A- Grup 1, ovaryum, primer folikül, östrojen $\alpha$ $(+)$; B- Grup 2, ovaryum, granulosa hücreleri, östrojen $\alpha$ $(+)$; C- Grup 3, ovaryum, primer folikül ve germinatif epitel, östrojen $\alpha(+)$; D- Grup 3, ovaryum, tersiyer follikül, teka interna ve externa, östrojen $\alpha(+)$.

Figure 1. Display of ovarian estrogen $\alpha$ staining in Groups 1,2 , 3. A- Group 1, ovary, primary follicle, estrogen $\alpha(+)$; B- Group 2, ovary, granulosa cells, estrogen $\alpha(+)$; C- Group 3 , ovary, primary follicle and germinative epithelium, estrogen $\alpha(+)$; D- Group 3, ovary, tertiary follicle, theca interna and externa, estrogen $\alpha(+)$.

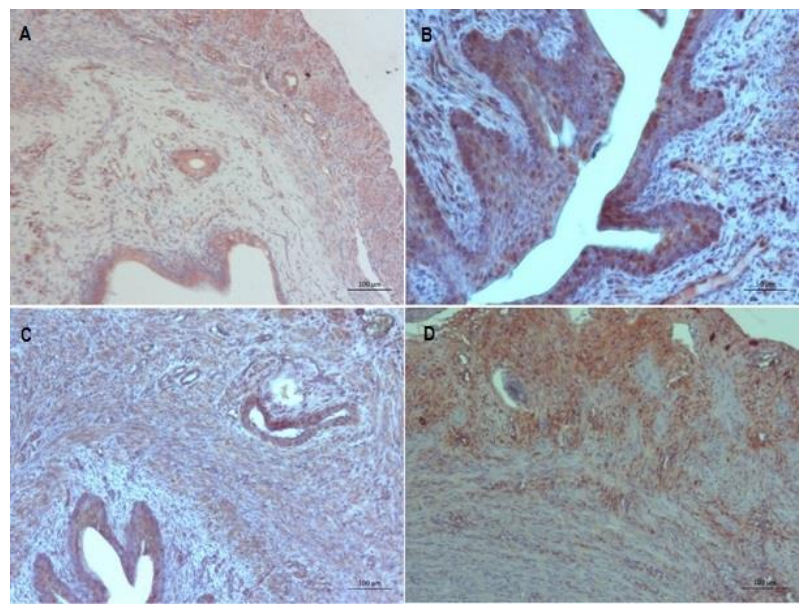

Şekil 2. Korpus uteri östrojen $\alpha$ boyamalarının Grup 1, 2, 3 de gösterimi. A- Grup 1, korpus uteri, östrojen $\alpha(+)$; BGrup 2, korpus uteri, endometrium, östrojen $\alpha(+)$; C- Grup 1 , korpus uteri, endometrium, epitel ve bezde östrojen $\alpha(+)$; D- Grup 3, korpus uteri, myometrium, östrojen $\alpha(+)$.

Figure 2. Representation of corpus uteri estrogen $\alpha$ staining in Groups 1, 2, 3. A- Group 1, corpus uteri, estrogen $\alpha(+)$; B- Group 2, corpus uteri, endometrium, estrogen $\alpha(+)$; C- Group 1, corpus uteri, endometrium, epithelium and gland estrogen $\alpha(+)$; D- Group 3, corpus uteri, myometrium, estrogen $\alpha(+)$. 


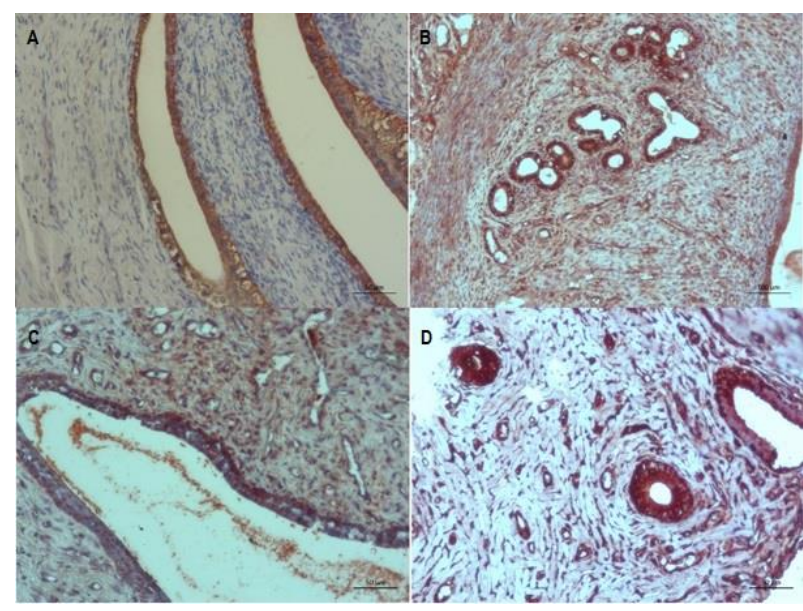

Şekil 3. Kornu uteri östrojen $\alpha$ boyamalarının Grup 1, 2, 3 de gösterimi. A- Kontrol kornu uteri, Östrojen $\alpha(+)$; B- Grup 1 , kornu uteri, endometrium bez epiteli, östrojen $\alpha(+)$; CGrup 2, kornu uteri, endometrium, östrojen $\alpha(+)$; D- Grup 2 , kornu uteri, endometrium bezleri, östrojen $\alpha(+)$.

Figure 3. Display of Kornu uteri estrogen $\alpha$ staining in Groups 1, 2, 3. A- Control corn uteri, Estrogen $\alpha$ (+); BGroup 1, cornu uteri, endometrial gland epithelium, estrogen $\alpha(+)$; C- Group 2, cornu uteri, endometrium, estrogen $\alpha(+)$; D- Group 2, cornu uteri, endometrial glands, estrogen $\alpha(+)$.

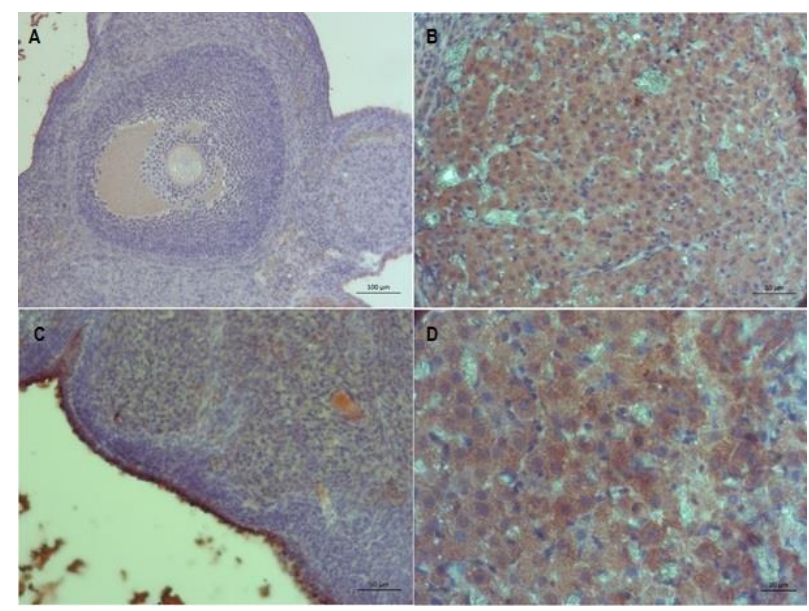

Şekil 4. Ovaryum PR-B boyamalarının Grup 2, 3 de gösterimi. A- Grup 2, ovaryum, teka externa, PR-B (+); BGrup 2, ovaryum, luteal hücreler, PR-B (+); C- Grup 3, ovaryum, germinatif epitel, PR-B (+); D- Grup 3, ovaryum, luteal hücreler, PR-B (+).

Figure 4. Display of ovary PR-B staining in Group 2, 3. AGroup 2, ovary, theca externa, PR-B (+); B- Group 2, ovary, luteal cells, PR-B (+); C- Group 3, ovary, germinative epithelium, PR-B (+); D- Group 3, ovary, luteal cells, PR-B $(+)$.

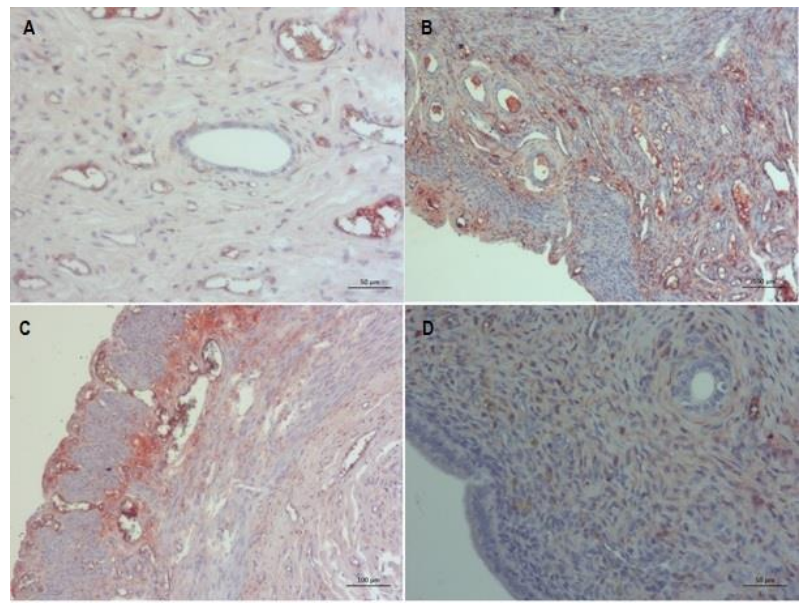

Şekil 5. Kornu uteri PR-B boyamalarının Kontrol ve Grup 2, 3 de gösterimi. A- Kontrol grubu, kornu uteri, PR-B (+); B- Kontrol grubu, korpus uteri, PR-B (+); C- Grup 2, kornu uteri, PR-B (+); D- Grup 3, kornu uteri, PR-B (+).

Figure 5. Display of Kornu uteri PR-B staining in Control and Group 2, 3. A- Control group, cornu uteri, PR-B (+); BControl group, corpus uteri, PR-B (+); C- Group 2, cornu uteri, PR-B (+); D- Group 3, cornu uteri, PR-B (+).

\section{TARTIŞMA ve SONUÇ}

Ratlarda östrüs siklusunun değişik dönemlerinde östrojen ve progesteron reseptörlerinin araştırıldığı birçok çalışma bulunmaktadır. Yapılan bu çalıșmada da farklı doz ve sürelerde eksojen GnRH uygulamasinın östrojen ve progesteron reseptörleri üzerine immünohistokimyasal etkileri incelenmiştir.

GnRH düşük dozda uygulanması ile ovulasyon üzerine etkili olarak görülmüştür. Ratlarda yapılan çalışmada uygulanan GnRH ovulasyonun baskılanması üzerinde etkili belirlenmiştir (Reissmann ve ark. 2000). Uzun süreli GnRH uygulamaları ise FSH ve LH konsantrasyonuna etki ederek folikül gelişimine, uterus ağırlığına, ovaryum makroskopi ve mikroskopisine, östrus siklus bulguları üzerine etkili görülmüştür (Janssens ve ark. 2000).

Yapılan çalıșmada ovaryum, uterusda makroskopik ve mikroskobik değişimler olduğu tanımlandı. Ovaryumda folikül gelişimini sayısal ve yapısal olarak arttırdığı belirlendi. Uterus da kornu, korpus bölümlerinde yapısal farklılaşmaların başladığı östrojen ve progesteron reseptörlerinin boyanma șiddeti ve boyanma yoğunlukları üzerine etkili olduğu görüldü. Bu sonuçlar uzun süreli GnRH uygulamasının ovaryum ve uterus üzerine etkili olduğunu ifade eden Soltysik ve ark. (2014)'nın çalışması ile uyum göstermektedir. Soltysik ve ark. (2014), GnRH uygulamasının iki hafta süreden sonra siklus üzerine, folikülogenezis üzerine, ovulasyon üzerine, androjen reseptörlerinin, östrojen reseptörlerinin ve progesteron reseptörlerinin stroma ve çekirdek yerleșimi üzerine etkili olduğu uterusta ise yapısal değişime sebep olduğu tespit edilmiştir. Yapılan çalışma ise 10 gün ve 5 gün $\mathrm{GnRH}$ uygulamalarının reseptör yerleșiminde boyanma şiddet ve yoğunluk bakımından etkili görülmüştür. Pogesteron reseptörlerinin10 gün ve 5 gün GnRH uygulanan gruplarda ovaryum ve uterusun iki kısmında daha yoğun olması luteinizasyon üzerine $\mathrm{GnRH}$ etkisini düşündürmektedir. GnRH uygulamalarının bu iki grupta folikülogenezisin ve östrojen $\alpha$ 'nın immunohistokimyasal reaksiyon şiddetinin arttığl görülmüștür (Roth ve ark. 2000). GnRH uygulamalarının 10 gün süreden daha az uygulanmasında uterusda ağırlık kaybı șekillenmediği, yapısal olarak 
preparatlarda da farklılık görülmediği söylenmiștir. Yapılan bu çalıșmada ise Östrojen $\alpha$ ve Preogesteron B reseptörlerinin yoğunluklarının tek doz uygulamada değişmediği 5 gün ve 10 gün uygulamalarında ise benzer olarak değişimin olduğu tespit edilmiștir. Soltysik ve ark. (2014) çalışmalarında ovaryum ve uterusta uzun süreli uygulamalarla değișikliklerin olduğu ve hormonal geri dönüşümün olabildiği belirtilmiștir.

Östrojen $\alpha$ reseptörünün farelerde uterus duvar kalınlığı uterus hacmi ve infertilite üzerine etkili olduğunu araștırılmış ve etkili olduğu belirlenmiştir (Chen ve ark. 2009). Farelerde desidua formasyonu ile östrojen progesteron reseptörlerinin bağlantılı olduğu bildirilmiştir (Winuthayanon ve ark. 2010). Yapılan çalışmada da GnRH uygulamalarından uterus endometriyum bez hücreleri ve epitel hücrelerinin etkilenmiș olması östrojen ve progesteron reseptör yoğunluğunun hormonal değişimden etkilendiği uygulama süre ve dozu arttıkça etkinin değiştiği belirlenmiștir. Östrojen reseptörlerinin ve progesteron reseptörlerinin dağılımının, rolünün ovaryum ve uterusta, benzer olmadığı bildirilmiștir (Winuthayanon ve ark. 2010). Yapılan çalışmada da östrojen $\alpha$ ve progesteron B nin yerleșim yerlerinin farklı olduğu tespit edilmiştir. Yapılan çalışmada GnRH uygulamalarının östrojen $\alpha$ ve progesteron B ekspresyonu üzerine etkisi araștırlarak tek doz uygulama da kontrol grubuna benzer olan yoğunluk ve yerleşimde reseptörler belirlenmiştir. Beș ve on gün uygulamarında ise östrojen $\alpha$ ekspresyonun ovaryum ve uterusta yer yer boyanma şiddeti olarak arttığı görülmüștür. Progesteron B nin ise ovaryumda üç gruptada benzer yoğunluk ve yerleşimde olduğu uterusta ise on gün GnRH uygulama yapılan grupta ise endemetriyum ve miyometriyum bölgelerinde artış gösterdiği görülmüştür.

Teilman ve ark. (2006), PR-B reseptörlerinin sığırlarda sekonder ve tersiyer foliküller, granüloza hücreleri, teka interna ve teka eksterna hücrelerinde lokalize olduğu bildirilmiştir. Progesteron üretiminin sadece granülosa hücreleriyle değil, aynı zamanda teka interna ve teka eksterna tarafından da üretilebildiği sonucuna varılmıștır. Ayrıca, progesteronun sığırlarda daha önce bildirildiği üzere PR'nün immünohistokimyasal olarak boyaması üzerinde olumsuz bir etkisi olduğu bildirilmiştir (Haeseleer ve ark. 2006). Ratlarda yapılan çalışmada kontrol grubunda korpus luteum luteal hücrelerinin yoğun ve şiddetli pozitif olarak boyandığı görüldü. Korpus albikanslarda zayıf pozitiflik, germinatif epitelde ise orta şiddette pozitiflik ve yoğun olarak her alanın boyandığı görüldü. Grup 1 ovaryum örneklerinde progesteron B reseptörlerinin korpus luteuma ait luteal hücrelerde orta ve zayıf (+) immunohistokimyasal reaksiyon verdiği belirlendi. Grup 2 ye ait ovaryum örneklerinde irili ufaklı korpus luteum sayısının fazla olduğu görüldü. Luteal hücrelerde yoğun reaksiyon ve boyanma derecesi orta ve güçlü belirlendi. Germinatif epitel ve bazı stromal hücrelerde de $(+)$ boyanmalar görüldü. Teka interna ve eksterna larda progesteron B $(+)$ reaksiyon zayıf olarak tespit edildi. Grup 3 ovaryum kesitlerinde de korpus luteum sayısının fazla olduğu, luteal hücrelerde de yoğun boyanma reaksiyonları belirlendi. Germinatif epitelde progesteron B güçlü (+) olarak tespit edildi.

İneklerde yapılan bir başka çalışmada (Akbalık ve ark. 2011), luteal ve folliküler fazda ovaryumlarda ER ve PR'lerinin lokalizasyonu ve yoğunluğu karşılaştırılmış ve PR-B'nin immünohistokimyasal olarak germinal epitel, stroma hücreleri, korpus albicans ve CL'da pozitif reaksiyon (+) verildiği, ER- $\alpha$ 'nın granülosa, germinal epitelyum hücrelerinden primer folikül hücrelerinde immünhistokimyasal olarak (+) reaksiyon cevap verildiği bildirilmiștir. Lokalizasyonun olarak incelenen rat ovaryumunda benzer sonuçlar elde edilmiştir.

Teilman ve ark. (2006), farelerde yaptıkları bir çalışmada, uygulama yapılmayan grupta PR zayıf boyandığı fakat farelere hCG uygulaması ile yapılan boyamalar sonucu güçlü bir şekilde boyandığı tespit edilmiştir. Granulosa hücreleri, preovulator folliküllerin boyandığı kumulus hücrelerinin boyanmadığı tespit edilmiștir (Teilman ve ark. 2006). Bu boyanma derecelerinin ve reaksiyon gücünün GnRH ile hCG uyarımı ile boyanma özelliklerinin artırılabileceğini göstermektedir. Yapılan çalıșma Teilman ve ark. (2006)'nın sonuçları ile uyumludur.

Mevcut sonuçlar değerlendirildiğinde; ratlara GnRH'ın tek enjeksiyonu ve tekrarlayan enjeksiyonları ile ovaryum ve uterusta ER $\alpha$ ve PR-B reseptörlerinin (+) reaksiyonlar gösterdiği belirlenmiștir. Tekrarlayan dozlarda GnRH enjeksiyonunun ER $\alpha$ ve PR-B reseptörlerinin dağılımlarına, yoğunluğuna kısmen etkili olduğu, boyanma reaksiyonuna şiddetine ise etkili olduğu sonucuna varılmıştır. Yapılan bu çalışmadaki GnRH hormon uygulamalarının, ileride yapılacak olan üreme hormonu uygulamalarının, immünohistokimyasal etkilerinin araștırıldığı çalışmalara kaynak teșkil edeceği ve bu konudaki literatüre katkı sağlayacağı düşünülmektedir.

\section{ÇIKAR ÇATIŞMASI}

Yazarlar, çıkar çatıșması olmadığını beyan eder.

\section{TEŞEKKÜR}

Çalıșmamızı, VF-049 nolu proje ile destekleyen, Sivas Cumhuriyet Üniversitesi Bilimsel Araştırma Projeleri Başkanlığına teşekkür ederiz.

\section{KAYNAKLAR}

Akbalık ME, Sağsöz H, Saruhan BG (2011). Localization of estrogen receptor alpha and progesterone receptor B in the bovine ovary during the follicular and luteal phase of the sexual cyle. Kafkas Univ Vet Fak Derg, 17, 795-802

Bancroft JD, Cook HC (1984). Manuel of Histological Techniques. Churchill Livingstone Inc. New York.

Brown NM, Lamartinere CA (2000). Genistein regulation of transforming growth factor-a, epidermal growth factor (EGF) and EGF Receptor expression in the rat uterus and vagina. Cell Growth Differ, 11, 255-260.

Chiang CH, Cheng KW, Igarashi S ve ark. (2000). Hormonal regulation of estrogen receptor alpha and beta gene expression in human granulosaluteal cells in vitro. J Clin Endocrinol Metab, 85, 3828-3839.

Chen M, Wolfe A, Wang X ve ark. (2009). Generation and characterization of a complete null estrogen receptor alpha mouse using Cre/LoxP technology. Mol Cell Biochem, 1-2, 145-153.

Delman HD, Eurell JA (1988). Textbook of Veterinary Histology, $5^{\text {th }}$ ed Williams-Wilkins London pp: 252-325.

Drummond AE, Findlay JK (1999). The role of estrogen in folliculogenesis. Mol Cell Endocrinol, 151, 57-64.

Graham JD, Clarke CL (1997). Physiological action of progesterone in target tissues. Endocr Rev, 18, 502-519.

Haeseleer MD, Simoens P, Van den Broeck W (2006). Cell- spesific localizaion of progesteron receptors in the bovine ovary at different stages of the oestrou s cycle. Anim Reprod Sci, 98, 271-281.

Hild- Petito S, Stouffer RL, Brenner RM (1988). Immunocytochemical localization of estrodiol and progesterone receptors in the monkey ovary throughout the menstrual cycle. Endocrinology, 123, 2896-2905.

Hulas-Stasiak M, Gawron A (2007). Immunohistochemical localization of estrogen receptors ER alpha and ER beta in the spiny mouse (Acomys Cahirinus) ovary during postnatal development. J Mol Hist, 38, 25-32.

Janssens RM, Brus L, Cahill DJ ve ark. (2000). Direct ovarian effects and safety aspects of GnRH agonists and antagonists. Hum Reprod Update, 6, 505-518. 
King JA, Millar RP (1995). Evolutionary aspects of gonadotropin-releasing hormone and its receptor. Cell Mol Neurobiol, 15, 5-23.

Merk FB, Botticelli CHR, Albright JT (1972). An intercellular response to estrogen by granulosa cells in rat ovary; an electron microscope study Endocrinology, 90, 992-1007.

Reissmann T, Schally AV, Bouchard $\mathbf{P}$ ve ark. (2000). The LHRH antagonist cetrorelix: a review. Hum Reprod Update, 6, 322-331.

Rosenfeld CS, Yuan X, Manikkam M ve ark. (1999). Cloning, sequencing and localization of bovine estrogen receptor-beta within the ovarian follicle. Biol Reprod, 60, 691-697.

Roth $\mathbf{C h}$, Leonhardt S, Seidel $\mathbf{C H}$ ve ark. (2000). Comparative analysis of different puberty inhibiting mechanisms of two GnRH agonists and the GnRH antagonist cetrorelix using a female model. Pediatr Res, 48, 468474.

Schams D, Berisha B (2002). Steroids as local regulators of ovarian activity in domestic animals. Domestic Anim Endocrinol, 23, 53-65.

Slomczynska M, Wozniak J (2001). Differential distribution of estrogen receptor beta and estrogen receptor alpha in the porcine ovary. Exp Clin Endocrinol Diabetes, 109, 238-244.

Soltysik K, Czekaj P, Suszka-Switek A ve ark. (2014). Changes in the subcellular and tissue location of estrogen and progesterone receptors in rat uterus after long-term treatment with analogs of gonadoliberin. Ginekol Po,l 85, 254-263.
Srisuwatanasagul S, Tummaruk P, Kunavongkrit A (2009). Studies of oestrogen and progesterone receptors in reproductive organs of prepubertal gilts with reproductive disturbance. Thai J Vet Med, 40, 1524.

Teilmann SC, Clement CA, Thorup J ve ark. (2006). Expression and localization of the progesterone receptor in Mouse and human reproductive organs. J Endocrinol, 191, 525-535.

Van den Broecck W, D'Haeseleer $M$ ve ark. (2002). Cell-specific distribution of progesteron receptors in the bovine ovary. Reprod Domest Anim, 37, 164-170.

Vermeirsch H, Simoens P, Ccorijn M ve ark. (2001). Immunolocalization of progesterone receptors in the canine ovary and their relation to sex steroid hormone concentrations. Reproduction, 122, 73-83.

Wei LL, Miner R (1994). Evidence for the resistance of a third progesterone receptor protein in human breast cancer line T47D. Cancer Research, 54, 340-343.

Winuthayanon W, Hewitt SC, Orvis GD ve ark. (2010). Uterine epithelial estrogen receptor is dispensable for proliferation but essential for complete biological and biochemical responses. Proc Natl Acad Sci, 45, 19272-19277. 